\title{
EVALUATION OF THE ANIMAL HUSBANDRY ECONOMY AND MEAT CONSUMPTION IN THE EARLY AND CLASSICAL DEVELOPMENTAL PHASES OF THE LUSATIAN CULTURE IN WITÓW, SITE 1, KOSZYCE COMMUNE
}

\begin{abstract}
Archaeological excavations conducted since 2002 in Witów, site 1, Koszyce commune have provided a large collection of animal bone remains. Analysis of this source category became the basis for evaluating the economic model in the early and classical developmental phases of the Lusatian settlement on this site. In both analyzed chronological periods, the basis for obtaining meat was animal husbandry. The dominant component in the analyzed collection is that of cattle bone remains, followed by sheep and goats as well as pigs in third place. Such species distribution indicates a plant cultivation/animal husbandry economy with a large share of pastoral traditions. One of the important areas of natural resource management was the collection of freshwater bivalves, which probably resulted from natural conditions. The low percentage of wild animal remains indicates that hunting played a marginal role in the sphere of economic activity of the communities analyzed. The lack of noticeable transformations in the domestic animals management system suggests that the economic model chosen in the early settlement phase turned out to be the most optimal strategy in relation to the environmental realities. A comparative analysis of the animal husbandry economy in Witów with other settlements of the Lusatian culture in Małopolska (Lesser Poland) and Śląsk (Silesia) showed some common trends. The obtained results indicate that apart from environmental pressure, cultural considerations and animal husbandry tradition to some extent determined the choice of the economic model.
\end{abstract}

KEY WORDS: Lusatian culture, animal husbandry economy, Bronze Age, archaeozoology

In considerations regarding prehistoric economies, including animal husbandry, natural sources play an extremely important role. It is impossible to analyze the animal husbandry structure or the type of crop in prehistory, without detailed research on animal bone remains, plant macroremains, and pollen. Therefore, based on a comprehensive archaeozoological analysis, while taking into account all other archaeological sources and the context of individual deposits, one can try to reconstruct the prehistoric economy. Individual archaeozoological studies are known from the areas occupied by specific Lusatian culture groups in Poland. The results of these analyses are more widely discussed in articles by D. Makowiecki and M. Makowiecka (1998) as well as by A. Gręzak and J. Piątkowska-Małecka (2007).

In turn, for the areas of Małopolska (Lesser Poland) a shortage of synthetic approaches in the context of this issue in the Lusatian culture is no- 


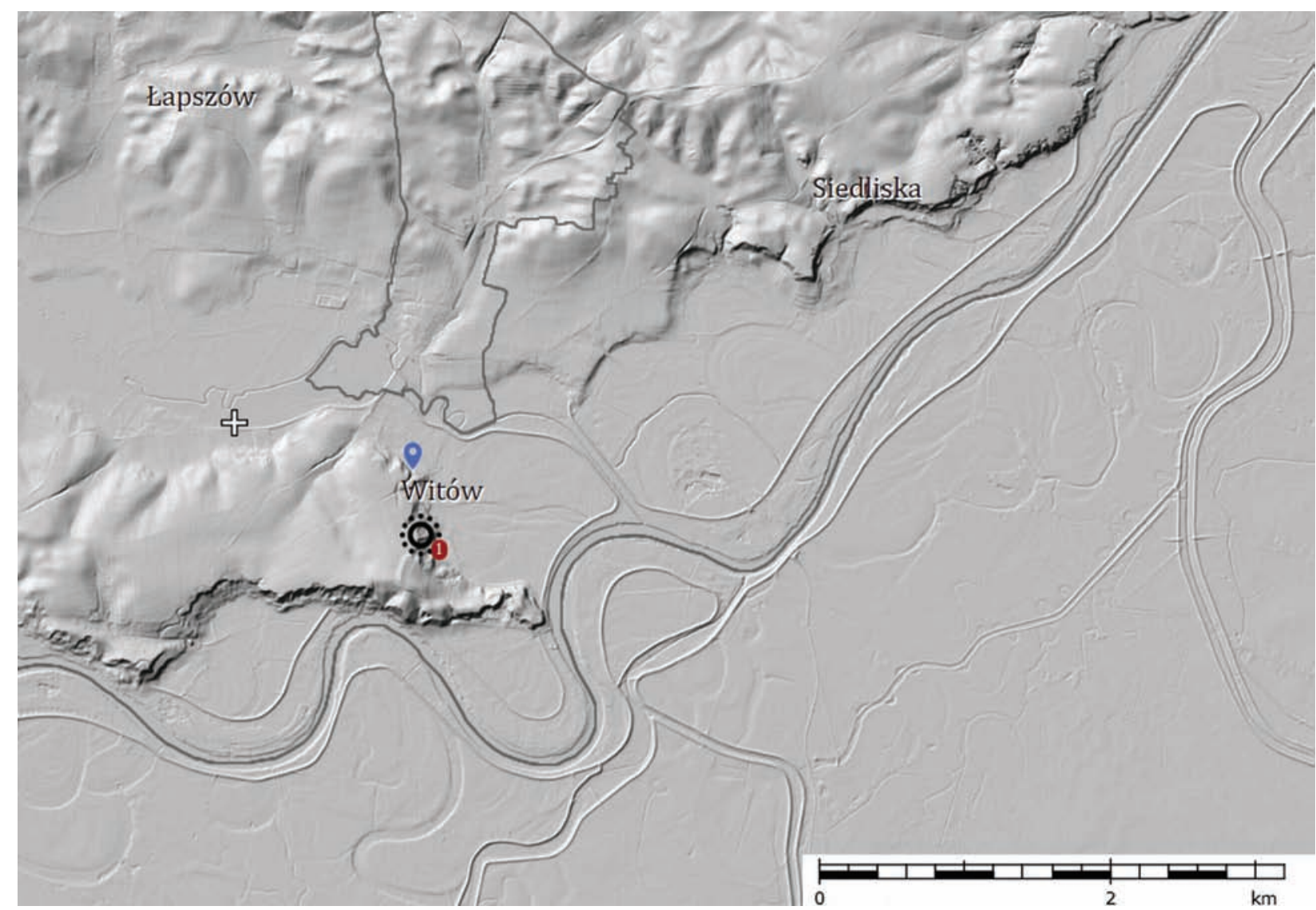

Fig. 1. Location of site No. 1 in Witów, Koszyce commune. Source: https://mapy.zabytek.gov.pl/nid/

ticeable. For this reason, research on bone remains from the Lusatian settlement in Witów, site 1, Koszyce commune is of particular importance. This is one of the first comprehensive studies of such a large collection of bone remains, and it brings a new quality to this type of study. It may also be used in the future as comparative material for other researchers dealing with this issue.

Site No. 1 in Witów, Koszyce commune, from which faunal material for research was obtained, is located within the upland promontory at the confluence of the Vistula and the Szreniawa rivers (Fig. 1). This promontory is called the 'Witów spur' and is the final section of the eastern part of the range of hills stretching for about 10 kilometres. The first excavations on this site were of a rescue nature and were carried out by S. Zemełka in 1960, and for the next three seasons by J. Marciniak (Marciniak 1963; 1964; 1965). Stationary excavations started not until 1980 under the direction of J. Rydzewski. Then excavation activities in the settlement in Witów were suspended for the next twenty years. Since 2002, systematic stationary excavations have been car- ried out at this site, during which fortifications of a stronghold erected by the Lusatian culture community were discovered (Gawlik and Godlewski 2006; 2007; 2009; 2010; 2012) and the multicultural character of the site was confirmed, as indicated by earlier excavations conducted by J. Marciniak (1963) and J. Rydzewski (1972; 1981; 1982).

Based on the analysis of the forms and style of pottery vessels and artefacts made of metal, two main chronological phases were distinguished, during which the development of the Lusatian settlement in Witów took place. The first one corresponds to the early phase of the Upper Silesian-Lesser Poland group and is dated to the III-IV period of the Bronze Age (around 1350-950 BC). It can be associated with the settlement of the Kraków subgroup identified with the population arrived from the region of the Głubczyce concentration (Gawlik and Godlewski 2006). The next stage was associated with the classical phase of the Upper SilesianLesser Poland group, whose development took place in the $\mathrm{V}$ period of the Bronze Age (hereinafter $\mathrm{V}$ OEB) and in the Hallstatt $\mathrm{C}$ period (here- 
inafter Ha C) (around 950-620/600 BC). Artefacts found in features dated to the III and IV periods of the Bronze Age show the greaes analogy within the Silesian group of the Lusatian culture, especially from Upper Silesia (Gawlik and Godlewski 2006; $2009)^{1}$. The development of settlement in this period is also confirmed by $14 \mathrm{C}$ dates from features 120 and 138, which are between 1350-1100 BC (Gawlik and Godlewski 2009, Table 1). Sparsely appearing metal products with significant dating values are primarily bronze hoards from J. Marciniak's studies dating to the IV Bronze Age period (Marciniak 1966; Blajer 2001, 336). The lack of features from younger chronological periods suggests that the Lusatian settlement in Witów did not continue during the Ha D period (Biskupice-Tyniec phase in Krakow area).

\section{Materials and methods}

Osteological material was obtained during the 2002-2009 excavation seasons and consisted of 3,001 bone fragments from mammals, birds, fish, and freshwater bivalve remains (Table 1). It should be mentioned that some of the material obtained during the 2002-2007 excavation seasons (512 specimens from the Lusatian culture features, 2,739 from the cultural layer) became the subject of archaeozoological analysis, the results of which provided preliminary information on the animal husbandry economy on this site (Zielińska 2009). The studied faunal samples were obtained from fills of 166 settlement features. $23.84 \%$ of the material was not identifiable due to the lack of diagnostic features. This value indicates a good state of preservation of the material, which was probably due to favourable soil conditions in which the bone substance was deposited. From the layers of 34 early Lusatian culture features 487 bone remains were obtained, of which about a quarter was not identified in terms of species and anatomical affiliation. In turn, 1,863 osteological units were found in fills of 73 features from the classical Lusatian culture phase. Almost

1 The issues concerning cultural changes in the Lesser Poland region in the III period of the Bronze Age are discussed, amongst others, by the following authors: J. Górski 2010, pp. 105-121; Ł. Mrówka 2014; M. S. Przybyła 2017, pp. $227-233$. a fifth of the examined collection dated to this phase was not identifiable.

Part of the pottery material did not have features of adequate chronological sensitivity and enabled only a general determination of its belonging to the Lusatian culture. This group includes 59 archaeological features, from which a total of 502 remains of various animal species and 149 fragments of freshwater bivalve shells were obtained (Table 1). Due to the lack of precise dating, this faunal material was excluded from the analysis.

The examined bone set was macroscopically examined using analytical procedures described in archaeozoological literature, mainly in the publication by A. Lasota-Moskalewska (2008).

Based on the diagnostic features occurring in skeletons specifying the animal species or other systematic unit, a zoological identification was made, during which a reference collection was used, which is the equipment of the University Centre of Veterinary Medicine UJ-UR. In addition, comparative animal anatomy textbooks were used (Barone 1976; Hillson 1999; France 2009). Bone remains of birds were isolated without recognizing their species and anatomical affiliation.

The anatomical distributions of cattle, sheep, goats, and pigs were compared with the reference anatomical distribution prepared for these species (Lasota-Moskalewska 2008, 238).

In order to distinguish between bone elements of sheep and goat, the criteria described by M. A. Zeder and H. A. Lapham (2010) were used. In cases where it was impossible to distinguish the bone remains of these species, the sheep/goat term conventionally adopted in archaeozoological studies was used.

Based on the observation of the degree of fusion of long bone epiphyses with shafts (Kolda 1936) and based on teeth development assessment (Lutnicki 1972), the age of animals was assessed.

Cattle sex was determined using the metacarpal and metatarsal bones width and length indicator (Hovard 1963). Pigs sex was determined based on the analysis of the transverse cross-section of tusks from the lower or upper rows and the outlines of their alveoli (Habermehl 1975, 135; Schmid 1972, 81).

Osteometric analysis was carried out based on the recommendations contained in the study by A. von den Driesch (1976). The morphological type of domestic animals was assessed using 
point scales developed for cattle by A. LasotaMoskalewska (1984) and H. Kobryń and A. LasotaMoskalewska (1989), for pig by A. Lasota-Moskalewska, H. Kobryń and K. Świerzyński (1987) and for horse by H. Kobryn (1989). The height at the withers of cattle was estimated using the coefficients by V. I. Calkin (1960) or J. Fock (1966).

The next stage of archaeozoological analysis was the comparison of the obtained results with other research carried out for the Lusatian culture settlements. Because of the unsatisfactory state of research on bone material from this period for Lesser Poland, material from the area of Silesia (both Upper and Lower) was chosen for comparative purposes. This was supported by both the state of research on osteological material from this area and the close cultural links between these areas.

\section{Species composition of faunal materials from the early developmental phase of the Lusatian culture (III - IV OEB)}

In the early Lusatian culture materials domesticated mammals are represented by the remains of cattle, sheep, goats, horses, and dogs. In this group the largest share constitute remains of small ruminants, but the bone components belonging to cattle are less frequent by only $3 \%$. The third place in terms of frequency is taken by bones of pigs and dogs, whose share is equal. Much less frequent are horse remains (Table 2). It should be noted, however, that the vast majority of dog bone remains (fragments of front and back limbs of one individual) were deposited in feature No. 314 (Table 3). Similarly, in the case of skeletal remains of sheep, a significant part of them was found in feature No. 261 and represented the front part of the body and fragments of the back limb of one individual (Table 4). The bone material from these two features differed from the others by degree of fragmentation and had no traces associated with cooking. For this reason, it was considered not to be postconsumption waste and was excluded from further analysis. Such a procedure significantly affects the order of occurrence of individual species and causes that the most frequent will be bone remains of cattle, not sheep and goats, which in turn indicates a different economic model. Only two elk bone remains were obtained from wild mammals (Table 2).
In the studied osteological assemblage the remains of birds constitute only a fraction of a percent of the total examined set. In turn, the remains of freshwater bivalve are represented more frequently (Table 1).

\section{Species composition of faunal materials from the classical developmental phase of the Lusatian culture (V OEB - Ha C)}

In features associated with the classical phase, similarly to older materials, there is a definite predominance of the remains of domesticated mammals over other taxa. Bone remains belonging to cattle followed by small ruminants were the most numerous in this group. One-fifth of the total collection was made up of pig bone remains. Even fewer elements belonging to horses were recorded, while dog bones do not exceed $2 \%$ of the analyzed sample (Table 5). Game is represented by individual bone elements belonging to red deer, roe deer, and beaver (Table 5). In addition, 16 striped field mouse skeleton elements were identified. Assuming that these animals were not bred for consumption or hunted, the identified remains were excluded from the analysis. The presence of mouse remains in the material in question probably results from the fact that it is a synanthropic species. Birds remain constituted a negligible percentage of the examined collection, while malacofauna is represented in large numbers. It is worth noting that about $41 \%$ of the studied faunal sample consists of freshwater bivalve shells. One part of a fish skeleton was also recorded.

\section{Comparison of species composition of bone remains obtained from features dated to the early and classical phases of the Lusatian culture}

A comparative analysis of faunal materials from the early and classical stages of the development of the Lusatian culture in Witów showed that the order of occurrence of the main domesticated species is the same, while small changes concern the percentage. Such results were obtained after exclusion from the materials of the early Lusatian culture bone remains from features 261 and 314, assuming that these deposits were not a manifestation of economic behaviour. 
Both in the early and classical phases, the predominant component is that of bone remains of cattle, followed by sheep and goats. In terms of number, bone remains of pigs are in third place in both examined chronological phases. Dog bone remains, which in the early Lusatian culture assemblages constituted a fraction of a percent of the examined bone set, appear more often in the classical phase (Table 6). Due to the small number of skeletal elements of horses and dogs in the studied faunal assemblages, it cannot be clearly determined whether the reason for the changes in their frequency concerned random factors, or whether it was a real change in the breeding system of these animals. In both analyzed developmental phases of the Lusatian settlement in Witów, bone remains of wild animals appear but in trace amounts, though it is worth noting that in the early Lusatian culture materials elk remains were found, while in classical materials - roe deer, beaver, and red deer.

\section{Anatomical composition of faunal materials from the early developmental phase of the Lusatian culture (III - IV OEB)}

Amongst bones of cattle, small ruminants, and pigs, few bone elements were recognized, though they do represent all parts of the cranial and postcranial skeleton.

In the case of cattle remains, the most frequent were bone elements coming from the trunk, followed by the head and proximal sections of the thoracic limb, i.e., the shoulder. From the distal part of the thoracic limb and proximal pelvic limb (the ham), the same number of elements were recognized. The distal section of the pelvic limb was represented by two tarsus bones and three metatarsal bone fragments. In addition, three phalanges were identified (Table 7).

In the anatomical composition of small ruminants, bones from the head part, the proximal part of the pelvic limb, and then the trunk were the most numerous. Distal sections of the fore and hind limbs as well as phalanges are represented by individual bone elements (Table 7).

Amongst the remains belonging to pigs, most elements come from the trunk part, the proximal part of the thoracic limb, and then the head. The remaining parts of the carcass are represented by individual bone elements (Table 7).
The results of the anatomical identification of the remaining species, whose few remains represented an incomplete skeleton, are presented in Table 7.

\section{Anatomical composition of faunal materials from the classical developmental phase of the Lusatian culture (V OEB - Ha C)}

Percentage data obtained for individual cattle bone assemblages showed that the remains included in the so-called brawn do not deviate from the norm, while disharmonies in relation to the standard distribution were noted amongst the elements constituting the postcranial skeleton. Surpluses were noted in relation to the proximal sections of the thoracic and pelvic limb (i.e., the so-called shoulder and ham) and the distal section of the pelvic limb. In turn, the deficiencies concern elements from the trunk part, distal sections of the thoracic limbs and phalanges (Table 9).

In the anatomical distribution of small ruminants, deficiencies were noted amongst the bone elements from the head, trunk and phalanges parts. Bone remains from the proximal sections of the thoracic and pelvic limbs occur in significant surpluses, while the ones from distal parts of the limbs do not differ from the standard distribution (Table 9).

Percentage data referring to pig bone assemblages show surplus amongst elements included in the head part, proximal sections of the thoracic limbs and proximal and distal sections of the pelvic limbs. Deficiencies were noted in relation to the elements constituting the trunk, distal sections of the thoracic limb and phalanges (Table 9).

The list of bone remains of other species, occurring in a number not exceeding 100 osteological units in the anatomical system was included only in Table 8.

\section{The age of death of domesticated animals whose remains were obtained from features of the early developmental phase of the Lusatian culture (III - IV OEB)}

Based on the observation of the age of cattle death, it was established that mainly mature individuals were intended for slaughter. The number of remains of juvenile individuals is within the 
boundary of the economic norm adopted for this species, which is $5-8 \%$ (Lasota-Moskalewska 2008,250 ) (Table 10). In this group, the metacarpal bone belonging to an individual between 2 and 2.5 years of age was recorded, as well as the tibia and metatarsal bone from animals which did not exceed 2 years of age at the time of death.

In the collection of bone remains of small ruminants over $35 \%$ belonged to animals slaughtered at a young age. This result is well above the generally accepted norm for these species, ranging from 5 to $8 \%$ (Lasota-Moskalewska 2008, 250) (Table $10)$. In the group of remains belonging to immature individuals, two fragmentarily preserved mandibles of animals slaughtered at about 18 months of age and a fragment of tibia of an individual that at the time of death did not exceed 3.5 years were distinguished.

About three-quarters of the identified pig bone remains belonged to morphologically immature individuals. This result is twice the economic norm adopted for this species, which is within $30-35 \%$ (Lasota-Moskalewska 2008, 250) (Table 10). In this group, bones belonging to individuals slaughtered in the first week of life ( 5 elements), between the 4th-6th month (1 element), before the 12th month (4 elements), and before the second year of life (3 elements) were identified.

All identified horse bone elements belonged to mature individuals, while amongst the dog bones one came from a young individual.

\section{The age of death of domesticated animals whose remains were obtained from features of the classical developmental phase of the Lusatian culture (V OEB - Ha C)}

In the cattle bone collection, the percentage of remains belonging to individuals slaughtered at a young age is $6.18 \%$ (Table 10), and therefore falls within the norm generally adopted for ruminants (5-8\% after Lasota-Moskalewska 2008, 250). In this group a fragment of the mandible of the individual was identified, which at the time of death was between the 24th and the 28th month, two metacarpal bones belonging to individuals intended for slaughter before reaching the second year of life, and a fragment of tibia of an animal about 3.5-year-old.

Almost half of the bone remains of small ruminants came from individuals slaughtered before reaching morphological maturity (Table 10). This result is well above the norm adopted for these species, which is the same as for cattle. This indicates a non-standard approach to husbandry and slaughter techniques in a herd of small ruminants. In the group of remains derived from young animals the following were distinguished: fragments of four mandibles belonging to individuals between the $3 \mathrm{rd}$ and the 4th month of age, a fragment of mandible and a tibia of individuals slaughtered before reaching the 18th month of age, a fragment of mandible of an animal between the 18th and the 24th month of age, one fragment of metacarpal bone, tibia and metatarsal bone belonging to animals approximately 20-month-old, as well as humerus fragment, radius fragment and three femur fragments from individuals slaughtered before reaching 3.5 years of age.

The percentage of bone remains belonging to young pigs is almost the same as of small ruminants (Table 10) and is above the generally adopted economic norm. In this group the following were identified: mandible fragment of an individual slaughtered between the 4th and the 6th month of age, fragment of jaw and mandible of individuals slaughtered around the 12th month of age, as well as fragment of jaw and two mandibles fragments of animals slaughtered between the 16th and the 24th month of age.

Other taxa (horse, dog, red deer, roe deer, beaver) were mainly represented by bone remains belonging to morphologically mature individuals. Only three bone fragments of juvenile individuals were determined, which were identified as: a roe deer tooth, a horse femur fragment and a dog rib fragment.

\section{Comparison of the age profile of animals belonging to the main breeding species}

The distribution of the cattle death rate shows similar results for both of the analyzed developmental phases of the Lusatian settlement in Witów. In the examined bone assemblages the percentage shares of remains of juvenile individuals do not exceed the norm adopted for this species (Table 10).

Data on the age of slaughter of small ruminants showed that the survival profile of these animals is the same in the early and the classical phase (Table 10). It is noteworthy that the surplus of bone elements of morphologically immature individuals 
increases by $9.5 \%$ in the classical phase and is even more pronounced. Perhaps this means that the removing model for these animals consolidated over time.

Similarly in the case of pig remains, a significant surplus of piglet bone components was observed (Table 10). This trend is reduced by about $25 \%$ in the classical phase, however, when the bones of juvenile individuals still constitute almost a half of the collection. When comparing both assemblages one should remember the significant differences in their numbers.

\section{Sex analysis of domesticated animals whose remains were obtained from features dated to the early (III - IV OEB) and classical (V OEB - Ha C) developmental phases of the Lusatian culture}

The fills of the early Lusatian culture features contained only three bone remains enabling sex assessment. Amongst them were the bovine metacarpus belonging to a female individual, as well as the tusk and mandible fragment of a pig, which also came from females.

Equally poor data on the sex of domesticated animals were provided by materials obtained from the classical Lusatian culture features. Only four bone elements had features related to sexual dimorphism. The bovine metacarpal bone belonged to a female or an ox, while the two metatarsal bones of this species belonged to males. In turn, the shape of the cross section of the pig's tusk indicates that it belonged to a female individual.

\section{Osteometric analysis of animal bone remains obtained from features dated to the early developmental phase of the Lusatian culture (III - IV OEB)}

The early Lusatian culture materials provided in total 14 bone remains with metric characteristics, of which for four there are no adequate scales and coefficients enabling to infer the morphology (Table 11).

The metric values of three cattle bone remains identified as talus and two phalanges I, ranged between 32.5 and 42.5 points, according to A. LasotaMoskalewska's scale (1982-1984), which indicates the presence of medium height individuals. In turn, based on the length of the largest metacarpal bone, it was determined that the remains belonged to an individual measuring approximately $108 \mathrm{~cm}$ at the withers, and therefore of short stature (Table 11). Both short and medium height individuals are of the Bos taurus brachyceros type .

The values obtained based on measurements of the length of the largest metacarpal bone of a sheep indicate an individual measuring about $55 \mathrm{~cm}$ at the withers, representing a short stature form (Table 11).

Based on measurements of the total length of horse metacarpal bone, it was determined that it belonged to a short stature animal, measuring approximately $119 \mathrm{~cm}$ at the withers (Table 11).

\section{Osteometric analysis of animal bone remains obtained from features dated to the classical developmental phase of the Lusatian culture (V OEB - Ha C)}

In the assemblage of bone remains derived from cattle obtained from layers of features of the classical phase, 18 bone elements with metric features were distinguished. The values obtained after measuring two elements ranged from 24 to 27.5 points, which indicates the occurrence of short stature individuals. In turn, the metric values of the next 13 elements ranged between 32.5 and 67.5 points corresponding to medium height individuals (Table 12). Data obtained from measurements of the total length of two metacarpal bones of males indicate that these individuals measured approximately 107 and $109 \mathrm{~cm}$ at the withers. An analogous measurement of the female metatarsal bone enables us to estimate its height at the withers at about $107 \mathrm{~cm}$. The obtained results indicate the presence of short and medium height individuals representing the Bos taurus brachyceros form.

Based on the results obtained after measuring the total length of a goat metatarsal bone, it was determined that its height at the withers was almost $69 \mathrm{~cm}$ and therefore represented a short stature. In turn, measurements of total length of sheep metatarsal bones enabled us to estimate the height at the withers of this individual at about $53 \mathrm{~cm}$ (Table 12).

The dimensions of the proximal epiphyses of two radial bones of pigs, when transferred to point 
scales, enabled us to find out that the identified remains were from individuals representing domesticated form (Table 12).

The height at the withers of horse, estimated on the basis of measurements of the width of the distal epiphysis of the radial bone, indicates the occurrence of a short stature individual (Table 10).

\section{Comparison of the results of osteometric analysis of bone remains obtained from features dated to the early and classical phases of the Lusatian culture}

Studies on the lability of morphological forms of the main slaughter species in Witów were based on attempts to reconstruct the height at the withers. This feature is best perceptible in osteological materials and clearly depicts possible transformations occurring in the skeleton of animals as a result of environmental changes or the intervention of breeders.

The reconstructions of height at the withers of cattle carried out using point scales, the few bones of which were obtained from features dated to the early developmental phase of the Lusatian culture, indicate the presence of short and medium height individuals belonging to Bos taurus brachyceros. In the younger material, dated to the classical phase, the values obtained from the measurements of individual skeletal elements, as well as in the early Lusatian culture materials, indicate the occurrence of short and medium height individuals, but the predominance of the latter should be emphasized.

For the remaining species, analogies were observed for bone remains of small ruminants and horses. It should be noted, however, that only single bones with preserved metric characteristics were available here.

In features from the early developmental phase of the Lusatian culture, only one sheep bone remnant had preserved metric features. Based on measurements it was determined that the animal measured about $55 \mathrm{~cm}$ at the withers. Fills of features dated to the classical phase also provided only one fragment of sheep bone allowing for osteometric analysis. It was determined that the height of the individual from which the measured bone derived was about $53 \mathrm{~cm}$. This may indicate that the same form occurs in both analyzed chronological periods. Based on such scarce data, however, it cannot be stated that this form represented the entire population of small ruminants bred by inhabitants of Witów. Likewise, for horse bone remains, the data obtained are insufficient to characterize the general population of these animals. In the early phase materials, only one measurable element was identified, belonging to a horse about $119 \mathrm{~cm}$ high at the withers, and therefore the short stature one. In the bone collection from the classical phase from this species also only one measurable remnant was obtained, and its dimensions indicate the occurrence of an individual whose estimated height was about $121 \mathrm{~cm}$ at the withers and probably represented the same form as in older materials.

The comparative analysis was difficult not only due to the scarcity of the results, but also due to their different frequency in both assemblages. However, it can be seen that in both examined periods the animal sizes are similar and do not undergo significant transformations over time.

\section{Identification of traces on the surface of bones obtained from features dated to the early and classical phase of the Lusatian culture}

The analysis of traces observed on the surface of bone remains obtained from the layers of the early and classical Lusatian culture features showed that they were primarily post-consumption materials. The traces of culinary processing in the form of chopping, filleting, or cooking were recorded on numerous bone elements of cattle, sheep/goat, pigs, and horses. Numerous of the analyzed bone remains bear traces of contact with high temperature in the form of black or grey colour (Tables 13, 14). In this group, the remains of white colour, strong cracking, and changed shape were also identified, which means that the material had to be burnt at a temperature between $900^{\circ} \mathrm{C}$ and $1000^{\circ} \mathrm{C}$ (Kaczanowski et al. 1992). Materials of this type probably accidentally got into a hearth or were intentionally thrown into the fire during sanitary procedures or as fuel.

One element bearing traces associated with its use as a tool was distinguished in the early Lusatian culture materials. On a fragment of the femur shaft of a medium mammal, traces of smoothening were observed, which may have been created during craft working. However, the function of this item has not yet been established. The layers of the classical Lusatian culture features provided two remains 
bearing the marks of craft working. Smoothening was observed on the surface of a freshwater bivalve shell, which brings to mind the effect of 'jewellery' activities. Similar traces were observed on the shaft of a horse's splint bone. It is possible that due to its natural shape, resembling an awl, this bone was used as a piercing tool or an awl.

In the bone assemblage associated with the early developmental phase of the Lusatian culture lesions in the form of perforation were recorded at the distal epiphysis of sheep's metatarsal bone. This type of degeneration could have been the result of inflammation or decalcification caused by diet. In turn, in the classical Lusatian culture materials, pathological changes were recorded on the metapodial bone, humerus, and pelvis of cattle as well as on a pig's pelvis. The observed lesions in all cases were in the form of severe roughening at the acetabulum. Several bone remains bore traces left by predators (probably dogs) in the form of gnawing marks (Tables 13, 14). In general, traces of this type are quite common in faunal materials and indicate that the remnants remained on the surface for some time and became the object of interest for predators.

\section{Discussion of the results}

The results of the analysis of the composition of animal classes and species enable us to conclude that in both examined chronological periods the basis for the supply of meat and fat to the inhabitants of the settlement in Witów were domestic mammals. The selection of species for breeding did not change over time, which indicates a stable economic model. In the early Lusatian culture materials as well as in the younger ones, dated to the classical phase, the main component are bone remains originating from cattle. The remains of small ruminants and pigs are in second and third place respectively in terms of frequency. Intensive cattle husbandry, with less interest in small ruminants, indicates agro-animal husbandry economy. The presence of pig remains also confirms the sedentary settlement. In the context of culinary preferences, the obtained results show that beef was preferred over the consumption of goat meat, mutton, and pork. However, it is worth paying attention to some subtle changes in the percentage shares of slaughter species in the classical phase (Table 6). The observed slight de- crease in the percentage of cattle bone remains with the simultaneous increase in the number of skeletal elements of small ruminants may be an expression of some changes in the husbandry system of these animals as a result of environmental transformations. It should be taken into account that sheep and goats are animals with less feed requirements than cattle. It is also easier to move with them. Perhaps the inhabitants of Witów were forced to expand into new grazing lands, because the previously maintained ruminant population has exploited the area around the settlement. The faunal collection from Witów in terms of sequence and frequency of remains of individual breeding species differs not only from those of the Lusatian culture sites located near Kraków (Pleszów, site 17, Mogiła, site 55, site 62), but also from materials from the Silesian group of the Lusatian culture in Upper Silesia (Dębnica, Prusice commune) and Lower Silesia (GrodziecDorotka, Będzin commune and Grzybiany, Kunice commune). Species distribution of animal bone remains from the early phase of the Lusatian culture in Mogiła, site 55, Kraków commune (Gocman, under preparation) and Dębnica, Prusice commune (Sobociński 1973) showed a definite dominance of cattle, followed by small ruminants and pigs in third place. It should be noted here that before the 'Lusatian colonization' the settlement in Mogiła, p. 55, was used for a long time by the Trzciniec culture communities (Górski 1992; 1993; 1994; 1996; 2002; 2007). In turn, the settlement in Witów, site 1, was founded at the beginning of the III period of the Bronze Age by people from the Glubczyce Upland (Gawlik and Godlewski 2006). Species distribution of remains registered in Pleszów, site 17, Kraków commune (Gocman 2018) and Mogiła, site 62, Kraków commune (Gocman 2018) was also characterized by a definite dominance of cattle, but with a slightly greater interest in breeding pigs, whose remains in terms of frequency are in second place. The settlement in Pleszów was the largest settlement of the Lusatian culture from the early phase, while the settlement on site No. 62 in Mogiła was founded by the Lusatian culture population, probably already in phase D of the Bronze Age. At that time, however, it played a minor role in the developing settlement system (Górski 2002, 31). It can be noticed, therefore, that on sites with certified Trzciniec culture influence, which could include Mogiła 55 (Górski 1992; 1993; 1994; 1996; 2002; 2007) and possibly Witów site 1 (Gawlik 
2012) $)^{2}$, sheep and goat came second in terms of frequency, while on 'pure Lusatian' sites it was pigs. Such results suggest that the differences in the consumption model were dictated not only by environmental but also, to a certain extent, by cultural factors.

In the classical phase, the changes in the species distribution are perceptible in the form of the dominance of pig bone remains on sites in Mogiła, site 62, Kraków commune and Grodziec-Dorotka, Będzin commune (Kubasiewicz and Pawlikowski 1976). Increased pig breeding may be associated with the development of the settlement network and demographic peak, as well as with worsening of climatic conditions and social unrest (Dzięgielewski 2016). However, it is worth emphasizing that this may also be the result of certain husbandry traditions or habits from Silesia. Also in Pleszów, site 17, a change in food preferences is noticeable, consisting in the intensification of beef consumption while reducing interest in pigs (Gocman, under preparation). I assumed that the obtained image evidences the stabilization of agriculture, which was largely linked to the husbandry of this particular species. A similar species distribution was recorded in the area of Lower Silesia in Grzybiany (PiątkowskaMałecka et al. 2011).

In the classical phase the settlement in Witów was reorganized from an open to a fortified one, but the economic and consumption model did not change. This consistency may result from a conservative approach to the issue of animal management, although it is also likely that the economic model chosen in the early phase turned out to be the most optimal in relation to the environmental realities of the time. Zagórzyce, site 1, Kazimierza Wielka commune, is the only Lusatian culture settlement, where trends in the faunal material are similar to those recorded in Witów. On this site the dominance of cattle over small ruminants, as in Witów, is several percent, while the remains of pig are in third place (Gocman and Pieńkos 2012). This demonstrates the implementation of a similar breeding model.

In the examined osteological collection there occur also a few bone remains of horses and dogs. There were no traces associated with cooking treat-

2 Pit burials with clear Trzciniec culture traditions can be indirect evidence of the Lusatian-Trzciniec contacts in Witów, site 1 (Gawlik 2012). ment on their surface, however, it should be noted that they coexisted with post-consumption material. Due to the functions of these animals and their intravital values, they were not widely bred for consumption. However, eating dog meat or horse meat seemed rational in the face of difficult living conditions in the prehistory. There is no evidence that there is any cultural taboo prohibiting the consumption of these species within the Lusatian culture communities. Examples of eating dog meat are known from the Neolithic settlements, e.g., the Rzucewo culture in Niedźwiedziówka and Rzucewo, or the Funnel Beaker culture community in Stryczowice, Ćmielów, Ćmielów commune or in Gniechowice, Kąty Wrocławskie commune (Piątkowska-Małecka and Gubernat 2003, 207-241).

The significant accumulation of freshwater bivalve shells (feature 307) indicates the economic use of bivalves, probably for consumption, for both humans and domesticated animals. Supplementing the diet with bivalves was enabled by the proximity of the river. Bivalve meat becomes edible for humans only after heat treatment (Kurzawska 2008, 59). Freshwater bivalve shells excavated on site No. 1 in Witów showed no signs of being burnt and were not deposited in a layer of scorch. They were all white and very brittle. It is difficult to determine if they underwent heat treatment, but the fact that they were open may indicate this. The shells themselves could also be a valuable raw material for making jewellery or everyday items. The phenomenon of shell middens is known in the Lusatian culture (Dzieczkowski and Ostoja-Zagórski 1976; Dzieczkowski 2004; Kurzawska 2008; Rembisz et al. 2009; Zabilska 2012). The conclusions drawn from specialized malacological analyses provide knowledge not only about economic behaviour but also about the palaeoclimate (Zabilska 2012, 257).

Trace amounts of bone remains of wild animals, not exceeding $1 \%$ of the total collection, show that hunting did not play a significant role in the strategy of obtaining meat. It should be remembered that this state of affairs could have been influenced by skinning and cutting up the meat of wild animals at the hunting site, which in turn resulted in a decrease in the number of their bones in the faunal deposit in the settlement (Binford 1980; 1981). The results obtained may indicate a lack of hunting traditions. On the Lusatian culture sites located around Krakow (Pleszów, site 17, Mogiła, sites 55 and 62) the percentage of wild animal bones was 
equally low and did not exceed $2 \%$ of the total collection. Slightly larger number of their remains was recorded in faunal materials in settlements representing the Silesian group of the Lusatian culture (up to about $4 \%$ of the total collection). The exception is the settlement in Grodziec-Dorotka, Będzin commune, where bone remains of various wild species constituted $14.2 \%$ of the total examined collection (Piątkowska-Małecka 2013, 454).

Bearing in mind that each animal lives in a specific biotope, the presence of wild species in the analyzed bone collection enables to infer about the natural environment in which the settlement in question functioned. In older materials, dated to the early developmental phase of the Lusatian settlement in Witów, two bone elements belonging to elk were identified. The natural habitat for this species is wet deciduous forest (Brehm 1963). Of course, it should be remembered that animals migrate, changing living zones for a short time, or permanently in search of new grazing areas. However, it can be assumed that in the III and IV periods of the Bronze Age, the area around the settlement in Witów could have been forested and wet enough to create favourable conditions for this species. In the classical phase game was represented by individual bone elements of red deer, roe deer, and beaver. The presence of the latter is not surprising, due to the vicinity of the river. The natural environment of red deer is deciduous forest, while of roe deer is forest edge (Brehm 1963). Thus, the living zones of these species could have freely overlapped.

The distribution of skeletal elements of basic slaughter species (cattle, sheep/goat, pig) provides relevant information on specific behaviour within the socio-cultural system, such as the functional use of animals (or parts of them) within the settlement and waste disposal. Interpretation of results should therefore be based on the following findings: whether the deposit from which the bones originated was a refuse dump, whether there are butchering practices, whether the bones were used as material for tools production, or whether there occurred distribution of selected parts of the carcass as part of regional exchange, which were social relations (Grant 1984, 498). The analysis of the anatomical distribution of bone remains of breeding species in Witów was carried out to determine the slaughter techniques and meat distribution manner. The results of such analysis can be reliable provided that the required minimum number of 100 osteologi- cal and anatomically identified units (for a given species) has been reached. Only materials dated to the classical phase of the Lusatian culture were suitable for this type of research. The early phase bone collection was unfortunately too scanty and provided only general conclusions about the presence of remains from individual skeleton parts. For this reason, it is not possible to determine what the initial model of carcass cutting up was (in the older phase of settlement) and what changes underwent. The most representative collection, for which the distribution of skeletal elements as an indicator of carcass classes was made, came from the classical developmental phase of the Lusatian settlement in Witów. In this assemblage, the presence of all parts of carcasses amongst the remains of cattle, small ruminants and pigs was noted. The few phalanges of cattle, sheep, goats, and pigs, found in features' fills, evidence that the slaughter and cutting up the carcass could have taken place in the settlement, perhaps even at households. To date, however, no specific (separated) place of slaughter has been determined.

Amongst the remains of cattle, obtained from classical phase features, significant disharmonies associated with bone shortages from the trunk part, which is puzzling due to the significant slaughter value of this element, were noticed. Generally, in archaeozoological materials, the trunk is in excess, not only because of the numerous vertebrae and ribs included in this part of the carcass, but primarily because this element is cut up into small pieces in the cooking process. The head, in this case does not deviate from the norm. Although no evidence of chopping on mandibles was found in the examined assemblage, it cannot be excluded that this element was also treated as a delicacy. It had significant qualities, e.g., in the form of the masseter and nostrils muscles (Olszewski 2005). The shares of bone remains from the shoulder and ham, i.e., the highest-class elements, are similar and occur in surpluses. This means that ham and shoulder were eaten equally and their surplus may be the result of treatments related to the preparation of meat for consumption. Traces associated with cooking (chopping, contact with fire) noticed on metacarpal and metatarsal bones of cattle, evidence that the socalled legs were also a subject of culinary interest.

In the anatomical distribution of small ruminants, disharmonies in regard to the reference distribution most often concern the deficiencies. 
The deficiencies noted in the bone assemblages from the trunk part, however, seem to be unusual. Because it was an element with significant consumption values, it was cut up into pieces in the cooking process. This resulted in an increase in the number of bone remains from this part of skeleton in post-consumption material, which, however, is not observed in the analyzed collection. Deficiency of bone remains from the distal section of the thoracic limb (wrist, metacarpal bone) may be due to the fact that it was most often slaughter waste. The percentage relations of distal pelvic limb sections did not show any significant differences from the model approach. In turn, surpluses of bone elements from the so-called shoulder and ham, the most valuable in culinary terms, are probably the result of intensive portioning in order to allow wider distribution or easier cooking.

In the bone assemblage originating from pigs, the most frequent are bone elements from the head part and proximal sections of the thoracic and pelvic limbs. In the case of this species, the head is a valuable element in terms of consumption, although not as attractive as shoulder or ham, which percentage exceeds by several times the norms set in the standard distribution. These surpluses probably were created as a result of stronger portioning of these elements in the cooking process. The couple percent shortage of bone remains from the trunk part, which is generally represented in large numbers in post-consumption materials, seems surprising. It cannot be ruled out that this is a manifestation of behaviour related to e.g., taking meat out of the study area as a supply during a trip, as a tribute or on exchange object. There is a significant shortage of distal limb sections and phalanges, although in the case of pigs also these parts of the carcass had significant consumption values and did not constitute typical slaughter waste.

The occurrence of disproportions in individual parts of the carcass in regard to the reference distribution can be the basis for distinguishing two models: export and import ones. Amongst exportoriented animal husbandry communities, in bone material there occurs a predominance of skull fragments and lower parts of limbs, which are slaughter waste (Wattenmaker 1987a, 198; 1987b, 117). In turn, in settlements to which meat products were imported, bone fragments representing valuable parts of the carcass dominate in faunal materials. The lack of prevalence of one of these categories may indicate a lack of trade and exchange of animal products (Wattenmaker 1987a, 198) or, on the contrary, the exchange of whole animals (Marciniak 1996, 133). Regular distribution of fragments of various anatomical parts may indicate a self-sufficient economy, where animals were bred and killed in the settlement (Crabtree 1990, 166). Perhaps the disharmonies recorded in the Witów materials in regard to the reference anatomical distribution result from taphonomic factors, such as chopping in the process of preparing meat for consumption, as well as cultural ones constituting manifestations of various culinary habits. It should be noted, however, that the inhabitants of the settlement in Witów carefully used all animal products, which proves the thrifty management of meat and fat. Given the difficult dietary conditions in prehistory, this approach seems to be the most economical. With regard to these comments, it can be assumed that a definite surplus of ham and shoulder with shortage of trunk parts (for all species) may (at least to some extent) have been imported. It seems quite probable that the analyzed communities mainly operated based on a self-sufficient economy, which did not interfere with occasional trade or exchange.

It is worth remembering, however, that not all materials are found where they were originally deposited, which is related to spatially defined rules for removing impurities (Maltby 1985, 52). Searching for the answer to the question of where the slaughter and cutting up of animal carcasses took place, an analysis was carried out concerning the accumulation of phalanges and distal sections of limbs. Unfortunately, this search did not produce results. To date, it was not possible to determine features containing a particularly large fraction of those elements that would be associated with the place of slaughter and preliminary treatment of animal carcasses.

The quality and taste of consumed meat is determined by the age of slaughtered animals as well as by specific part of carcass from which the meat is obtained. The occurrence of repetitive patterns of such selection allows to determine the animal husbandry specialization, which on the one hand defines the nature of animal management, and on the other hand enables to determine to certain degree (although limited) the structure of the population. In prehistoric faunal materials, two types of death rate are distinguished: 'normal' one and 'catastrophic' (mass) one (Levine 1983, 23-34; Lyman 
1987, 126; Lasota-Moskalewska 2008, 252). The first of these types of death rate in a herd is characterized by high variability, resulting from the environmental conditions in which the herd is living as well as from breeding operations. In turn, the 'catastrophic' distribution occurs when the entire population dies out due to, for example, epidemics, drought, flood, etc. (Marciniak 1996, 119). Observations of the age of animal death are used in the interpretation of breeding operations used by prehistoric breeders. They help in findings (although not direct) regarding the occurrence of age classes in a given animal population resulting from breeding selection (Cribb 1987, 377). Slaughter age research has shown which age groups of animals were most likely to be consumed. Unfortunately, due to the small amount of data concerning the stages of individual development of particular species, it is not possible to trace reproduction and slaughter cycles. Therefore, it was limited to estimating the percentage relations between adults and those who did not reach morphological maturity. Observations of the age of cattle death showed that in both analyzed chronological periods the slaughter model was the same. Mainly morphologically mature individuals were slaughtered, but the percentage of animals killed at a young age was within accepted standards. This means that the so-called economic breeding, allowing for harmonious development of the population by selecting individuals for slaughter and for further reproduction, was carried out (Lasota-Moskalewska 2008, 250). In the case of small ruminants, the slaughtering system also did not undergo significant transformations as the Lusatian culture settlement in Witów developed. The percentage of remains of young sheep and goats definitely exceeds the norms adopted for these species, which means that these animals were bred for meat. The trend of slaughtering young individuals is deepening in younger materials, which may be an expression of the consolidation of the developed model. Animals from which blood, milk, or wool was obtained generally lived until old age (Reitz and Wing 2008, 192).

The pigs' death rate profile presents similar results both in the early and the classical phase. Pork was obtained mainly from immature individuals. It is worth noting, however, that this tendency decreases by $30 \%$ with time and the piglets are slaughtered less often. Such a strategy does not affect the stability of the pig population's development due to their reproductive abilities and the large number of young in one litter. Pigs, apart from the production of fertilizer, have no intravital value, which is why keeping them alive for a long time is not profitable from the point of view of prehistoric economy (Lasota-Moskalewska 2005, 250). Pigs were bred mainly to obtain meat and fat, the growth of which is the highest after 2 year of age (Lasota-Moskalewska 2005, 145) and during periods of the greatest abundance of food (Molenat and Casabianca 1979), which in turn may affect the seasonality of slaughter of these animals (Vigne 1998).

Data on the distribution of sex in the population of domesticated animals are too scarce to draw any conclusions. Therefore, we do not know whether this feature was subject to control and to what extent animal management was focused on dairy production and to what extent on meat production.

Osteometric analysis enabled determination of type and morphological forms of animals bred by prehistoric inhabitants of Witów. Most measurements were made on cattle bone remains. Based on the obtained parameters, it was established that both in the early and classical phases short-horned cattle of short or medium height, belonging to Bos taurus brachyceros, occurred. This means that throughout the entire period of the settlement operation, the population of animals of this species was local, stable and subject to one-way control. Short and medium height cattle inhabited the Polish territories since the Neolithic, hence the presence of its remains in the examined material is not surprising (Lasota-Moskalewska 2005, 67). Data on the morphology of small ruminants are so scarce that it is impossible to determine what the population of these animals looked like or whether any breeding treatments were used to obtain a specific feature. The remains of sheep obtained from the early and classical Lusatian culture features indicate the occurrence of individuals with dimensions similar to some contemporary breeds of sheep (Hołub 1938, 21; Folejewski 1948, 11-12). Amongst the bone remains of goats only one element had metric features preserved. The identified bone came from an individual representing the morphological type, which appeared in Poland around 5000 BC. (Lasota-Moskalewska 2005, 115). In the collection of pig bone remains only two bone elements with preserved metric features were identified (early phase of the Lusatian culture). Both specimens belonged to the domesticated pig form, not exceeding $80 \mathrm{~cm}$ 
at the withers and commonly found on Polish territory since the Neolithic (Lasota-Moskalewska $2005,138)$. Horses both in the early and classical phases represented the short stature type.

The view that has existed in the literature for a long time (e.g., Gedl 1961; Kurnatowski 1966; Rydzewski 1982; Lityńska-Zając 1997) that in the Lusatian culture community the basic means of obtaining food was agriculture and animal husbandry, found confirmation not only in inventory of artefacts (e.g., agriculture tools) from various settlements, but also in faunal material. In addition, there are arguments such as sedentariness, building large stable settlements in areas predestined for agriculture, and long-term use of burial grounds (Rydzewski 1982, 321-322).

\section{Conclusions}

The conducted research has shown that in both the early and classical phases, the basic strategy for obtaining meat involved cattle, small ruminants, and pigs. However, the hierarchy of species is noticeable in the meat production system, which is certainly also the result of the economic model applied. The predominant component of the animal population was cattle, followed by small ruminants and pigs. This indicates a plant cultivation-animal husbandry economy with a large share of pastoral traditions. The sedentary type of settlement additionally facilitated pig breeding. One of the important areas of natural resource management was the gathering of freshwater bivalves, which probably resulted from natural conditions. Hunting was of the least importance in the economic activity of the analyzed communities. Based on the results obtained, it can be concluded that the economic strategy of the communities living in the settlement in Witów, site 1 proved to be optimal, which was reflected in the stability of the consumption model chosen at the beginning.

The economic activity of local groups of the Lusatian culture was based on adaptation to environmental conditions, the choice of which was not accidental. The obtained results showed that, apart from environmental conditions, also cultural considerations and breeding tradition had a decisive influence on the choice of the breeding model. Certainly further research, on a larger sample, will be more comprehensive and will answer more questions. It is possible that the trends already perceptible will also be confirmed by analyses carried out on a larger number of sites.

Table 1. Taxonomic composition of remains on site No. 1 in Witów, Koszyce commune

\begin{tabular}{|l|c|c|c|}
\hline \multicolumn{1}{|c|}{ Taxon } & $\begin{array}{c}\text { Early phase } \\
\text { of the Lusatian culture } \\
\text { (III OEB - IV OEB) }\end{array}$ & $\begin{array}{c}\text { Classical phase } \\
\text { of the Lusatian culture } \\
\text { (V OEB - HA C) }\end{array}$ & $\begin{array}{c}\text { Lusatian culture } \\
\text { - no precise dating }\end{array}$ \\
\hline $\begin{array}{l}\text { Cattle } \\
\text { Bos primigenius } \\
\text { f. domestica (f. taurus) }\end{array}$ & 86 & 275 & 112 \\
\hline $\begin{array}{l}\text { Sheep/goat } \\
\text { Ovis/Capra }\end{array}$ & 54 & 224 & 84 \\
\hline $\begin{array}{l}\text { Goat } \\
\text { Capra aegagrus } \\
\text { f. domestica (f. hircus) }\end{array}$ & 3 & 3 & 3 \\
\hline $\begin{array}{l}\text { Sheep } \\
\text { Ovis orientalis } \\
\text { f. domestica (f. aries) }\end{array}$ & 38 & 6 & 4 \\
\hline $\begin{array}{l}\text { Pig } \\
\text { Sus scrofa f. domestica }\end{array}$ & 46 & 140 & 73 \\
\hline
\end{tabular}


EVALUATION OF THE ANIMAL HUSBANDRY ECONOMY AND MEAT CONSUMPTION IN WITÓW, SITE 1, KOSZYCE COMMUNE

\begin{tabular}{|c|c|c|c|}
\hline Taxon & $\begin{array}{c}\text { Early phase } \\
\text { of the Lusatian culture } \\
\text { (III OEB - IV OEB) }\end{array}$ & $\begin{array}{c}\text { Classical phase } \\
\text { of the Lusatian culture } \\
\text { (V OEB - HA C) }\end{array}$ & $\begin{array}{l}\text { Lusatian culture } \\
\text { - no precise dating }\end{array}$ \\
\hline $\begin{array}{l}\text { Horse } \\
\text { Equus ferus f. domestica }\end{array}$ & 19 & 39 & 13 \\
\hline $\begin{array}{l}\text { Dog } \\
\text { Canis lupus f. domestica } \\
\text { (f. familiaris) }\end{array}$ & 46 & 12 & 4 \\
\hline $\begin{array}{l}\text { Red deer } \\
\text { Cervuselaphus }\end{array}$ & 0 & 2 & 2 \\
\hline $\begin{array}{l}\text { Roe deer } \\
\text { Capreoluscapreolus }\end{array}$ & 0 & 1 & 3 \\
\hline $\begin{array}{l}\text { Elk } \\
\text { Alcesalces }\end{array}$ & 2 & 0 & 0 \\
\hline $\begin{array}{l}\text { Beaver } \\
\text { Castorfiber }\end{array}$ & 0 & 1 & 1 \\
\hline $\begin{array}{l}\text { Rodents } \\
\text { Rodentia }\end{array}$ & 0 & 16 & 1 \\
\hline $\begin{array}{l}\text { Birds } \\
\text { Aves }\end{array}$ & 3 & 2 & 0 \\
\hline $\begin{array}{l}\text { Bivalves } \\
\text { Bivalvia }\end{array}$ & 63 & 765 & 149 \\
\hline $\begin{array}{l}\text { Fish } \\
\text { Piscis }\end{array}$ & 0 & 1 & 0 \\
\hline $\begin{array}{l}\text { Human } \\
\text { Homo sapiens }\end{array}$ & 2 & 7 & 2 \\
\hline Unidentified & 125 & 369 & 200 \\
\hline Total & 487 & 1863 & 651 \\
\hline
\end{tabular}

Table 2. Species composition of animal bone remains obtained from the early Lusatian culture features on site No. 1 in Witów, Koszyce commune

\begin{tabular}{|c|c|c|c|c|}
\hline & \multicolumn{2}{|c|}{ Including features 261 and 314} & \multicolumn{2}{|c|}{ Without features 261 and 314} \\
\hline Species & $\mathrm{N}$ & $\%$ & $\mathrm{~N}$ & $\%$ \\
\hline Cattle & 86 & 29,45 & 79 & 42,47 \\
\hline Sheep/goat & 95 & 32,53 & 54 & 29,03 \\
\hline Pig & 46 & 15,75 & 42 & 22,58 \\
\hline Horse & 19 & 6,50 & 8 & 4,30 \\
\hline Dog & 46 & 15,75 & 3 & 1,61 \\
\hline Domesticated mammals & 292 & 100 & \multirow{4}{*}{186} & \multirow{4}{*}{100} \\
\hline Elk & 2 & 1068 & & \\
\hline Wild mammals & 2 & 0,00 & & \\
\hline Total & 294 & & & \\
\hline
\end{tabular}


Table 3. Anatomical composition of dog bone remains from feature No. 314 in Witów, site 1

\begin{tabular}{|c|c|c|c|c|c|c|}
\hline Inventory No. & Feature No. & Depth & Number of fragments & Species & Anatomical part & Left/right \\
\hline 41 & 314 & $110-120$ & 1 & Dog & Caudal vertebra & \\
\hline 41 & 314 & $110-120$ & 1 & Dog & Caudal vertebra & \\
\hline 41 & 314 & $110-120$ & 1 & Dog & Caudal vertebra & \\
\hline 41 & 314 & $110-120$ & 1 & Dog & Wrist bone & \\
\hline 41 & 314 & $110-120$ & 1 & Dog & Wrist bone & \\
\hline 41 & 314 & $110-120$ & 1 & Dog & Wrist bone & \\
\hline 41 & 314 & $110-120$ & 1 & Dog & Wrist bone & \\
\hline 41 & 314 & $110-120$ & 1 & Dog & Metacarpal bone & Right \\
\hline 41 & 314 & $110-120$ & 1 & Dog & Metacarpal bone & Right \\
\hline 41 & 314 & $110-120$ & 1 & Dog & Metacarpal bone & Right \\
\hline 41 & 314 & $110-120$ & 1 & Dog & Metacarpal bone & Right \\
\hline 41 & 314 & $110-120$ & 1 & Dog & Metacarpal bone & Left \\
\hline 41 & 314 & $110-120$ & 1 & Dog & Metacarpal bone & Left \\
\hline 41 & 314 & $110-120$ & 1 & Dog & Metacarpal bone & Left \\
\hline 41 & 314 & $110-120$ & 1 & Dog & Astragalus bone & Right \\
\hline 41 & 314 & $110-120$ & 1 & Dog & Astragalus bone & Left \\
\hline 41 & 314 & $110-120$ & 1 & Dog & Metatarsal bone & Right \\
\hline 41 & 314 & $110-120$ & 1 & Dog & Metatarsal bone & Right \\
\hline 41 & 314 & $110-120$ & 1 & Dog & Metatarsal bone & Right \\
\hline 41 & 314 & $110-120$ & 1 & Dog & Metatarsal bone & Right \\
\hline 41 & 314 & $110-120$ & 1 & Dog & Metatarsal bone & Left \\
\hline 41 & 314 & $110-120$ & 1 & Dog & Metatarsal bone & Left \\
\hline 41 & 314 & $110-120$ & 1 & Dog & Metatarsal bone & Left \\
\hline 41 & 314 & $110-120$ & 1 & Dog & Metatarsal bone & Left \\
\hline 41 & 314 & $110-120$ & 1 & Dog & Phalanx I & \\
\hline 41 & 314 & $110-120$ & 1 & Dog & Phalanx I & \\
\hline 41 & 314 & $110-120$ & 1 & Dog & Phalanx I & \\
\hline 41 & 314 & $110-120$ & 1 & Dog & Phalanx I & \\
\hline 41 & 314 & $110-120$ & 1 & Dog & Phalanx I & \\
\hline 41 & 314 & $110-120$ & 1 & Dog & Phalanx I & \\
\hline 41 & 314 & $110-120$ & 1 & Dog & Phalanx I & \\
\hline 41 & 314 & $110-120$ & 1 & Dog & Phalanx I & \\
\hline 41 & 314 & $110-120$ & 1 & Dog & Phalanx II & \\
\hline 41 & 314 & $110-120$ & 1 & Dog & Phalanx II & \\
\hline 41 & 314 & $110-120$ & 1 & Dog & Phalanx II & \\
\hline 41 & 314 & $110-120$ & 1 & Dog & Phalanx II & \\
\hline 41 & 314 & $110-120$ & 1 & Dog & Phalanx II & \\
\hline 41 & 314 & $110-120$ & 1 & Dog & Phalanx II & \\
\hline 41 & 314 & $110-120$ & 1 & Dog & Phalanx II & \\
\hline 41 & 314 & $110-120$ & 1 & Dog & Phalanx II & \\
\hline 41 & 314 & $110-120$ & 1 & Dog & Phalanx I & \\
\hline 41 & 314 & $110-120$ & 1 & Dog & Phalanx III & \\
\hline 41 & 314 & $110-120$ & 1 & Dog & Phalanx III & \\
\hline
\end{tabular}


Table 4. Anatomical composition of sheep bone remains from feature No. 216 in Witów, site 1

\begin{tabular}{|c|c|c|c|c|c|c|}
\hline $\begin{array}{l}\text { Inventory } \\
\text { No. }\end{array}$ & $\begin{array}{l}\text { Feature } \\
\text { No. }\end{array}$ & Depth & Fragments & Species & Anatomical part & Right/left \\
\hline $90 / 07$ & 261 & 140-bottom & 24 & Sheep & Skull & \\
\hline $90 / 07$ & 261 & 140-bottom & 3 & Sheep & Jaw & Right \\
\hline $89 / 07$ & 261 & $120-140$ & 1 & Sheep & Mandible & Right \\
\hline $90 / 07$ & 261 & 140-bottom & 1 & Sheep & Tooth & \\
\hline $90 / 07$ & 261 & 140-bottom & 1 & Sheep & Tooth & \\
\hline $86 / 07$ & 261 & $100-120$ & 1 & Sheep & Tooth & \\
\hline $90 / 07$ & 261 & 140-bottom & 1 & Sheep & Vertebra & \\
\hline $90 / 07$ & 261 & 140-bottom & 1 & Sheep & Vertebra & \\
\hline $90 / 07$ & 261 & 140-bottom & 1 & Sheep & Vertebra & \\
\hline $90 / 07$ & 261 & 140-bottom & 1 & Sheep & Vertebra & \\
\hline $90 / 07$ & 261 & 140-bottom & 1 & Sheep & Vertebra & \\
\hline $90 / 07$ & 261 & 140-bottom & 1 & Sheep & Vertebra & \\
\hline $90 / 07$ & 261 & 140-bottom & 1 & Sheep & Vertebra & \\
\hline $90 / 07$ & 261 & 140-bottom & 1 & Sheep & Vertebra & \\
\hline $90 / 07$ & 261 & 140-bottom & 1 & Sheep & Rib, shaft fragment & \\
\hline $90 / 07$ & 261 & 140-bottom & 2 & Sheep & Rib, shaft fragment & \\
\hline $90 / 07$ & 261 & 140-bottom & 1 & Sheep & Rib, shaft fragment & \\
\hline $90 / 07$ & 261 & 140-bottom & 1 & Sheep & Rib, shaft fragment & \\
\hline $90 / 07$ & 261 & 140-bottom & 1 & Sheep & Rib, shaft fragment & \\
\hline $90 / 07$ & 261 & 140-bottom & 1 & Sheep & Rib, shaft fragment & \\
\hline $90 / 07$ & 261 & 140-bottom & 1 & Sheep & Rib, shaft fragment & \\
\hline $90 / 07$ & 261 & 140-bottom & 1 & Sheep & Rib, shaft fragment & \\
\hline $90 / 07$ & 261 & 140-bottom & 1 & Sheep & Rib, shaft fragment & \\
\hline $90 / 07$ & 261 & 140-bottom & 1 & Sheep & $\begin{array}{l}\text { Rib, head and shaft } \\
\text { fragment }\end{array}$ & \\
\hline $90 / 07$ & 261 & 140-bottom & 1 & Sheep & $\begin{array}{l}\text { Rib, head and shaft } \\
\text { fragment } \\
\end{array}$ & \\
\hline $90 / 07$ & 261 & 140-bottom & 3 & Sheep & Scapula & Right \\
\hline $90 / 07$ & 261 & 140-bottom & 1 & Sheep & Metacarpal bone & Right \\
\hline $90 / 07$ & 261 & 140-bottom & 1 & Sheep & Metacarpal bone & Left \\
\hline $90 / 07$ & 261 & 140-bottom & 3 & Sheep & Humerus & Right \\
\hline $90 / 07$ & 261 & 140-bottom & 1 & Sheep & Humerus, shaft i block & Left \\
\hline $88 / 07$ & 261 & $120-140$ & 1 & Sheep & $\begin{array}{l}\text { Femur, head and shaft } \\
\text { fragment }\end{array}$ & Left \\
\hline $90 / 07$ & 261 & 140-bottom & 1 & Sheep & Tarsus bone & \\
\hline $88 / 07$ & 261 & $120-140$ & 1 & Sheep & Metatarsus bone & Left \\
\hline $90 / 07$ & 261 & 140-bottom & 1 & Sheep & Phalanx I & \\
\hline $90 / 07$ & 261 & 140-bottom & 1 & Sheep & Phalanx II & \\
\hline $90 / 07$ & 261 & 140-bottom & 1 & Sheep & Phalanx II & \\
\hline $90 / 07$ & 261 & 140-bottom & 1 & Sheep & Phalanx III & \\
\hline
\end{tabular}


Table 5. Species composition of animal bone remains obtained from features dated to the classical phase of the Lusatian culture on site No. 1 in Witów, Koszyce commune

\begin{tabular}{|l|c|c|}
\hline \multicolumn{1}{|c|}{ Species } & N & $\%$ \\
\hline Cattle & 275 & 39,34 \\
\hline Sheep/goat & 233 & 33,33 \\
\hline Pig & 140 & 20,03 \\
\hline Horse & 39 & 5,58 \\
\hline Dog & 12 & 1,72 \\
\hline Domesticated mammals & 699 & 100 \\
\hline Red deer & 2 & \\
\hline Roe deer & 1 & 0,57 \\
\hline Beaver & 1 & \\
\hline Wild mammals & 4 & \\
\hline Total & 703 & \\
\hline
\end{tabular}

Table 6. Comparison of species composition obtained from features dated to the early and classical phase of the Lusatian culture on site No. 1 in Witów, Koszyce commune

\begin{tabular}{|l|c|c|}
\hline \multicolumn{1}{|c|}{ Species } & Early phase & Classical phase \\
\hline & $\%$ & $\%$ \\
\hline Cattle & 42,47 & 39,34 \\
\hline Sheep/goat & 29,03 & 33,33 \\
\hline Pig & 22,58 & 20,03 \\
\hline Horse & 4,30 & 5,58 \\
\hline Dog & 1,61 & 1,72 \\
\hline Total & 100 & 100 \\
\hline
\end{tabular}

Table 7. Anatomical composition of bone remains of domesticated and wild mammals extracted from features dated to the early phase of the Lusatian culture on site No. 1 in Witów, Koszyce commune

\begin{tabular}{|l|l|l|l|l|l|l|l|l|}
\hline Anatomical part & cattle & sheep/goat & sheep & goat & pig & horse & dog & elk \\
\hline horn core & 2 & - & - & 1 & - & - & - & - \\
\hline skull & 5 & 1 & - & - & 1 & - & 1 & - \\
\hline jaw & 1 & 1 & - & - & 1 & - & - & - \\
\hline mandible & 6 & 7 & - & 2 & 3 & - & - & - \\
\hline tooth & 2 & 4 & - & - & 2 & - & - & - \\
\hline vertebra & 3 & 2 & - & - & 2 & - & - & 1 \\
\hline rib & 22 & 9 & - & - & 10 & 2 & 2 & - \\
\hline scapula & 5 & 3 & - & - & 4 & - & - & - \\
\hline humerus & 7 & 3 & - & - & 5 & - & - & - \\
\hline
\end{tabular}




\begin{tabular}{|l|l|l|l|l|l|l|l|l|}
\hline Anatomical part & cattle & sheep/goat & sheep & goat & pig & horse & dog & elk \\
\hline radius & 2 & 3 & - & - & - & 1 & - & - \\
\hline ulna & - & - & - & - & 1 & 1 & - & - \\
\hline metacarpal bone & 4 & 1 & - & - & 3 & - & - & - \\
\hline wrist bone & 4 & - & - & - & - & - & - & - \\
\hline pelvis & 1 & 2 & - & - & 1 & 2 & - & 1 \\
\hline femur & 2 & 3 & 1 & - & 1 & 1 & - & - \\
\hline tibia & 5 & 7 & - & - & 2 & - & - & - \\
\hline fibula & - & - & - & - & 1 & - & - & - \\
\hline astragalus & 1 & - & - & - & - & - & - & - \\
\hline tarsus bone & - & 1 & - & - & - & - & - & - \\
\hline calcaneus bone & 1 & 1 & - & - & 1 & - & - & - \\
\hline metatarsal bone & 3 & - & - & - & 1 & - & - & - \\
\hline phalanx I & 2 & 2 & - & - & 1 & 1 & - & - \\
\hline phalanx II & 1 & - & - & - & 1 & & - & - \\
\hline phalanx III & - & - & - & - & 1 & & - & - \\
\hline Total & 79 & 50 & 1 & 3 & 42 & 8 & 3 & 2 \\
\hline
\end{tabular}

Table 8. Anatomical composition of bone remains of domesticated and wild mammals obtained from features dated to the classical phase of the Lusatian culture on site N. 1 in Witów, Koszyce commune

\begin{tabular}{|l|l|l|l|l|l|l|l|l|l|l|}
\hline Anatomical part & cattle & sheep/goat & sheep & goat & pig & horse & dog & red deer & beaver & roe deer \\
\hline horn core & 3 & - & - & 2 & - & - & - & - & - & - \\
\hline skull & 28 & 8 & - & - & 9 & 2 & - & 1 & - & - \\
\hline mandible & 16 & 16 & - & - & 20 & 1 & - & - & - & - \\
\hline tooth & 11 & 10 & - & - & 18 & 5 & 3 & - & 1 & 1 \\
\hline vertebrae & 9 & 17 & - & - & 5 & 2 & 1 & - & - & - \\
\hline sternum & - & 1 & - & - & - & - & - & - & - & - \\
\hline rib & 75 & 64 & - & - & 31 & 10 & 4 & 1 & - & - \\
\hline scapula & 7 & 12 & - & - & 5 & 1 & - & - & - & - \\
\hline humerus & 15 & 10 & 1 & 1 & 6 & - & - & - & - & - \\
\hline radius & 11 & 19 & - & - & 5 & 2 & - & - & - & - \\
\hline ulna & 1 & 2 & - & - & 2 & 2 & 1 & - & - & - \\
\hline wrist bone & 3 & 2 & - & - & - & - & - & - & - & - \\
\hline metatarsal bone & 14 & 7 & 1 & - & 6 & 1 & 1 & - & - & - \\
\hline pelvis & 11 & 7 & - & - & 7 & 1 & 2 & - & - & - \\
\hline femur & 10 & 9 & - & - & 6 & 4 & - & - & - & - \\
\hline tibia & 14 & 24 & - & - & 5 & 2 & - & - & - & - \\
\hline fibula & - & - & - & - & 4 & - & - & - & - & - \\
\hline patella & 3 & 1 & - & - & - & - & - & - & - & - \\
\hline calcaneus bone & 2 & 1 & - & - & 1 & - & - & - & - & - \\
\hline
\end{tabular}




\begin{tabular}{|l|l|l|l|l|l|l|l|l|l|l|}
\hline Anatomical part & cattle & sheep/goat & sheep & goat & pig & horse & dog & red deer & beaver & roe deer \\
\hline astragalus & 1 & 2 & - & - & 1 & - & - & - & - & - \\
\hline tarsus bone & 3 & - & - & - & - & - & - & - & - & - \\
\hline splint bone & - & - & - & - & - & 3 & - & - & - & - \\
\hline metatarsal bone & 16 & 7 & 1 & 3 & 3 & - & - & - & - & - \\
\hline phalanx & 5 & 3 & - & - & 1 & 1 & - & - & - & - \\
\hline phalanx I & 11 & 2 & - & - & 5 & 1 & - & - & - & - \\
\hline phalanx II & 3 & - & - & - & - & - & - & - & - & - \\
\hline phalanx III & 3 & - & - & - & - & 1 & - & - & - & - \\
\hline Total & 275 & 224 & 3 & 6 & 140 & 39 & 12 & 2 & 1 & 1 \\
\hline
\end{tabular}

Table 9. Anatomical composition of bone remains of cattle, sheep/goats and pig obtained from features dated to the classical phase of the Lusatian culture on site No. 1 in Witów, Koszyce commune

\begin{tabular}{|l|l|l|l|l|l|l|}
\hline \multirow{2}{*}{} & \multicolumn{2}{|c|}{ cattle } & \multicolumn{2}{c|}{ sheep/goat } & \multicolumn{2}{c|}{ pig } \\
\cline { 2 - 8 } & \multicolumn{1}{|c|}{$\mathrm{n}$} & \multicolumn{1}{c|}{$\%$} & $\mathrm{n}$ & \multicolumn{1}{c|}{$\%$} & \multicolumn{1}{c|}{$\mathrm{n}$} & \multicolumn{1}{c|}{$\%$} \\
\hline head & 58 & 21,1 & 36 & 15,45 & 47 & 33,57 \\
\hline trunk & 84 & 30,54 & 82 & 35,2 & 36 & 25,71 \\
\hline Thoracic limb, proximal part & 34 & 12,36 & 45 & 19,31 & 18 & 12,86 \\
\hline Thoracic limb, distal part & 14 & 5,09 & 8 & 3,43 & 6 & 4,28 \\
\hline Pelvic limb, proximal part & 35 & 12,73 & 40 & 17,17 & 22 & 15,71 \\
\hline Pelvic limb, distal part & 28 & 10,18 & 17 & 7,30 & 5 & 3,57 \\
\hline phalanges & 22 & 8 & 5 & 2,14 & 6 & 4,3 \\
\hline Total & 275 & 100 & 233 & 100 & 140 & 100 \\
\hline
\end{tabular}

Table 10. Comparison of the percentage shares of bone remains of cattle, sheep/goat and pig, originating from individuals slaughtered at a young age, obtained from the Lusatian culture features on site No. 1 in Witów, Koszyce commune

\begin{tabular}{|l|l|l|l|l|}
\hline \multirow{2}{*}{ Species } & \multicolumn{2}{c|}{ Early phase } & \multicolumn{2}{c|}{ Classical phase } \\
\cline { 2 - 5 } & \multicolumn{2}{|c|}{$\mathrm{n} / \mathrm{N}$} & \multicolumn{1}{c|}{$\mathrm{n} / \mathrm{N}$} & \multicolumn{1}{c|}{$\%$} \\
\hline Cattle & $5 / 79$ & 6,33 & $17 / 275$ & 6,18 \\
\hline Sheep/goat & $19 / 54$ & 35,18 & $104 / 233$ & 44,63 \\
\hline Pig & $30 / 42$ & 71,43 & $62 / 140$ & 44,28 \\
\hline
\end{tabular}

$\mathrm{n}$ - morphologically immature individuals; $\mathrm{N}$ - total number of remains of a given species 
EVALUATION OF THE ANIMAL HUSBANDRY ECONOMY AND MEAT CONSUMPTION IN WITÓW, SITE 1, KOSZYCE COMMUNE

Table 11. Results of measurements of animal bone remains excavated from features dated to the early phase of the Lusatian culture on site No. 1 in Witów, Koszyce commune

\begin{tabular}{|l|l|l|l|l|l|l|l|l|l|}
\hline \multicolumn{1}{|c|}{ Species } & Anatomical part & GL & GLI & GLm & Bp & SD & Bd & BT & Pkt/WH \\
\hline cattle & humerus & - & - & - & - & - & - & 69 & no scale \\
\hline cattle & metacarpal bone & 180 & - & - & 50 & 28 & 56 & - & WH=108,0 cm \\
\hline cattle & astragalus & - & 59 & 54 & - & - & 36 & - & 32,5 \\
\hline cattle & phalanx I & 58 & - & - & 23 & 21 & 24 & - & 42,5 \\
\hline cattle & phalanx I & 53 & - & - & 26,5 & 22 & 26 & - & 32,5 \\
\hline sheep & humerus & - & - & - & - & - & 30 & 26 & no scale \\
\hline sheep & humerus & - & - & - & - & - & 30 & 26 & no scale \\
\hline sheep & metacarpal bone & 112 & - & - & 21 & 10 & 22 & - & WH $=54,8$ \\
\hline sheep & phalanx I & 33 & - & - & 11 & 8 & 10 & - & no scale \\
\hline horse & metacarpal bone & 196 & 186 & - & 46 & 30 & 45 & - & WH=119,2cm \\
\hline
\end{tabular}

Table 12. Results of measurements of animal bone remains obtained from features dated to the classical phase of the Lusatian culture on site No. 1 in Witów, Koszyce commune

\begin{tabular}{|l|l|l|l|l|l|l|l|l|l|}
\hline Species & $\begin{array}{l}\text { Anatomical } \\
\text { part }\end{array}$ & GL & \multicolumn{1}{|c|}{ GLI } & GLm & \multicolumn{1}{|c|}{ Bp } & \multicolumn{1}{|c|}{ SD } & Bd & BT & pkt/WH \\
\hline cattle & humerus & - & - & - & - & - & 74 & 66 & 48 \\
\hline cattle & $\begin{array}{l}\text { metacarpal } \\
\text { bone }\end{array}$ & - & - & - & 54 & 31 & - & - & 40 \\
\hline cattle & $\begin{array}{l}\text { metacarpal } \\
\text { bone }\end{array}$ & 175 & - & - & 60 & 34 & 62 & - & WH=109,4 cm \\
\hline cattle & $\begin{array}{l}\text { metacarpal } \\
\text { bone }\end{array}$ & 172 & - & - & 52 & 31 & 58 & - & WH=107,5 cm \\
\hline cattle & tibia & - & - & - & - & - & 62 & - & 44 \\
\hline cattle & tibia & - & - & - & - & - & 60 & - & 40 \\
\hline cattle & tibia & - & - & - & - & 39 & 59,5 & - & 40 \\
\hline cattle & tibia & - & - & - & - & - & 52 & - & 24 \\
\hline cattle & talus & - & 57 & 54 & - & - & 37 & - & 27,5 \\
\hline cattle & metatarsal bone & - & - & - & 48 & - & - & - & 60 \\
\hline cattle & metatarsal bone & 200 & - & - & 47 & 25 & 54 & - & WH=107 cm \\
\hline cattle & metatarsal bone & - & - & - & 40,5 & - & - & - & 35 \\
\hline cattle & phalanx I & 58 & - & - & - & - & - & - & 45 \\
\hline cattle & phalanx I & 63 & - & - & 30 & 25 & 2 & - & 67,5 \\
\hline cattle & phalanx I & 53 & - & - & - & - & - & - & 32,5 \\
\hline cattle & phalanx I & 57 & - & - & 25 & - & 23 & - & 42,5 \\
\hline cattle & phalanx I & 57 & - & - & 25 & - & 23 & - & 42,5 \\
\hline cattle & phalanx I & 59 & - & - & 30 & 24 & 28 & - & 47,5 \\
\hline goat & metatarsal bone & 129 & - & - & 19 & 11 & 22 & - & WH=68,9 cm \\
\hline goat & metatarsal bone & - & - & - & - & - & 23 & - & no scale \\
\hline
\end{tabular}




\begin{tabular}{|l|l|l|l|l|l|l|l|l|l|}
\hline Species & $\begin{array}{c}\text { Anatomical } \\
\text { part }\end{array}$ & GL & GLI & GLm & Bp & SD & Bd & BT & \multicolumn{1}{c|}{ pkt/WH } \\
\hline goat & metatarsal bone & - & - & - & - & - & 26 & - & no scale \\
\hline sheep & metatarsal bone & 117 & - & - & 18 & 9 & 21 & - & WH=53,1 cm \\
\hline sheep & humerus & - & - & - & - & - & - & 32 & no scale \\
\hline pig & radius & - & - & - & 28 & - & - & - & 26,66 \\
\hline pig & radius & - & - & - & 29 & - & - & - & 23,33 \\
\hline horse & radius & - & - & - & - & - & 66 & - & 23,33 \\
\hline
\end{tabular}

List of abbreviations: Ndo - unidentified bone; GL - maximal length; GLI - maximal length of lateral section of talus; GLm - maximal length of medial section; Bp - maximal width of proximal epiphysis;

BT - maximal width of block; SD - minimal width of shaft; Bd - maximal width of distal epiphysis

Table 13. Traces observed on surface of bones obtained from features dated to the early phase of the Lusatian culture on site No. 1 in Witów, Koszyce commune

\begin{tabular}{|l|l|l|}
\hline \multicolumn{1}{|c|}{ Species } & \multicolumn{1}{|c|}{ Number of fragments } & \multicolumn{1}{c|}{ Traces } \\
\hline medium mammal & 1 & craft working \\
\hline cattle, sheep/goat & 5 & culinary processing (chopping) \\
\hline cattle, sheep/goat & 13 & $\begin{array}{l}\text { heat treatment (black, white } \\
\text { discolouration) }\end{array}$ \\
\hline cattle & 2 & gnawing \\
\hline sheep & 1 & $\begin{array}{l}\text { lesions (perforation on distal epiphysis } \\
\text { of metatarsal bone) }\end{array}$ \\
\hline
\end{tabular}

Tabela14. Traces observed on surface of bones obtained from features dated to the classical phase of the Lusatian culture on site No. 1 in Witów, Koszyce commune

\begin{tabular}{|l|l|l|}
\hline \multicolumn{1}{|c|}{ Species } & \multicolumn{1}{|c|}{ Number of fragments } & \multicolumn{1}{c|}{ Traces } \\
\hline horse, shell & 2 & craft working \\
\hline $\begin{array}{l}\text { cattle, sheep/goat, pig, horse, } \\
\text { ndo }\end{array}$ & 35 & $\begin{array}{l}\text { culinary processing (chopping, filleting, } \\
\text { cooking) }\end{array}$ \\
\hline $\begin{array}{l}\text { cattle, sheep/goat, pig, shell, } \\
\text { ndo }\end{array}$ & 13 & $\begin{array}{l}\text { heat treatment (black, grey } \\
\text { discolouration) }\end{array}$ \\
\hline cattle, sheep/goat & 4 & gnawing by predators \\
\hline cattle, pig & 4 & lesions (osteochondrosis, perforation) \\
\hline cattle & 2 & post-deposition traces - roots \\
\hline
\end{tabular}




\section{BIBLIOGRAPHY}

Barone R. (1976). Anatomie comparée des mammifères domestiques, t. 1. Osteologie, Fasc. 2, Atlas. Paris.

Binford L.R. (1978). Nunamiut etnoarchaeology. New York: Academic Press.

Binford L.R. (1981). Bones: Ancient Men and Modern Myths. New York: Academic Press.

Blajer W. (2001). Skarby przedmiotów metalowych z epoki brazu $i$ wczesnej epoki żelaza na ziemiach polskich. Kraków: Księgarnia Akademicka.

Brehm A. (1963). Życie zwierząt. Ssaki. Warszawa: PWN.

Całkin V.I. (1960). Izmiencivost metapodii i jego znacenie dlja izucenija krupnogorogatogo skota drevnosti. Bjulletin Moskovskogo Obscestva Ispytatelej Prirody, 65, 1, 109-126.

Crabtree P.J. (1990). Zooarchaeology and complex societies: some uses of faunal analysis for the study of trade, status, and ethnicity. In: M.B. Schiffer (ed.), Archaeological method and theory (Vol. 2) (155-205). Tucson: University of Arizona Press.

Cribb R.L.D. (1987). The logic of the herd: a computer simulation of archaeological herd structure. Journal of Anthropological Archaeology, 6, 376-415.

Diakowski M., Zych J. (2014). Analiza archeozoologiczna materiału kostnego ze stanowiska Grzybiany. In: T. Stolarczyk, J. Baron (eds), Osada kultury pól popielnicowych w Grzybianach koło Legnicy. LegnicaWrocław: Muzeum Miedzi w Legnicy.

Driesch A. von den. (1976). A guide to the measurement of animal bones from archaeological sites. Cambridge: Peabody Museum Bulletin 1, Peabody Museum of Archaeology and Ethnology, Harvard University.

Dzięczkowski A. (2004). Materiały malakologiczne i botaniczne. In: T. Malinowski (ed.), Komorowo stanowisko 1. Grodzisko kultury tużckiej i osadnictwo wczesnośredniowieczne. Badania specjalistyczne (139-146). Zielona Góra: Oficyna Wydawnicza Uniwersytetu Zielonogórskiego.

Dzięczkowski A., Ostoja-Zagórski J. (1976). Próba zastosowania analizy malakologicznej do rekonstrukcji środowiska przyrodniczego na przykładzie grodziska halsztackiego z Jankowa, woj. Bydgoszcz. Archeologia Polski, 21(2), 319-353.

Fock J. (1966). Metrische Untersuchungen an Metapodien einiger europäischer Rinderrasen. Dissertation, University of Munich.

Fojelewski W. (1948). Studia nad karnówką (polską owca krajowa). Kraków: Nakładem Polskiej Akademji Umiejętności.
France D.L. (2009). Human and Nonhumane Bone Identification. A color atlas. CRC Press.

Gawlik A. (2012). Pochówki szkieletowe ze st. 1 w Witowie - interpretacja obrządku pogrzebowego. In: W. Blajer (ed.), Peregrinationes archaeologicae in Asia et Europa Joanni Chochorowski Dedicate (341348). Kraków: Instytut Archeologii Uniwersytetu Jagiellońskiego / Wydawnictwo Profil-Archeo.

Gawlik A., Godlewski P. (2006). Ein Bericht von den Ausgrabungen an der Fundstelle 1 in Witów, Gde. Koszyce in der Saison 2002-2003. Recherches Archéologiques, 112-118.

Gawlik A., Godlewski P. (2007). Monety piastowskie z Witowa. Alma Mater, nr specjalny 99/2008, 85-88.

Gawlik A., Godlewski P. (2009). Rescue excavations at site 1 in Witów, Proszowice district, seasons 2004-2006. Recherches Archéologiques, 83-99.

Gawlik A., Godlewski P. (2010). Elementy zakarpackie w materiałach wczesnołużyckich ze st. $1 \mathrm{w}$ Witowie, gm. Koszyce. In: J. Gancarski (ed.), Transkarpackie kontakty kulturowe $w$ epoce kamienia, brąu $i$ wczesnej epoce żelaza (331-352). Krosno: Muzeum Podkarpackie w Krośnie.

Gardawski A. (1979). Zagadnienia wytwórczości. In: A. Gardawski (ed.), Prahistoria ziem polskich, Tom IV: Od środkowej epoki brązu do środkowego okresu lateńskiego (257-263). Wrocław: Ossolineum.

Gedl M. (1961). Uwagi o gospodarce $i$ strukturze społecznej ludności kultury tużyckiej w południowej Polsce. Kraków: Uniwersytet Jagielloński.

Gocman U. (2018). Gospodarka hodowlana na obszarach lessowych Zachodniej Małopolski w środkowej i późnej epoce brązu i wczesnej epoce żelaza (Rozprawa doktorska w Archiwum Instytutu Archeologii Uniwersytetu Jagiellońskiego).

Gocman U., Pieńkos I. (2012). Gospodarka hodowlana na terenie wielokulturowej osady w Zagórzycach, gm. Kazimierza Wielka (od III okresu epoki brązu do wczesnego okresu wpływów rzymskich. In: W. Blajer (ed.), Peregrinationes archaeologicae in Asia et Europa Joanni Chochorowski Dedicate (331-340). Kraków: Instytut Archeologii Uniwersytetu Jagiellońskiego / Wydawnictwo Profil-Archeo.

Górski J. (1992). Uwagi o schyłkowych fazach kultury trzcinieckiej i początkach kultury łużyckiej na terenie Nowej Huty. Materiały Archeologiczne Nowej Huty, $15,63-72$. 
Górski J. (1993). Osada kultury trzcinieckiej i łużyckiej w Nowej Hucie-Mogile, stanowisko 55. Analiza materiałów I. Materiały Archeologiczne Nowej Huty, 16, 55-102.

Górski J. (1994). Osada kultury trzcinieckiej i łużyckiej w Nowej Hucie-Mogile, stan. 55. Analiza materiałów II. Materiaty Archeologiczne Nowej Huty, 17, 65-113.

Górski J. (1996). Osadnictwo kultury trzcinieckiej na skraju terasy Wisły w Nowej Hucie. Materiały Archeologiczne Nowej Huty, 20, 7-37.

Górski J. (2002). Zmiana organizacji sieci osadniczej na obszarze Nowej Huty w środkowym okresie epoki brązu. Materiaty Archeologiczne Nowej Huty, 23, 17-39.

Górski J. (2007). Chronologia kultury trzcinieckiej na lessach Niecki Nidziańskiej. Biblioteka Muzeum Archeologicznego w Krakowie 3. Kraków.

Górski J. (2010). Migration and cultural change. Western Lesser Poland in 1300-1200 BC. In: K. Dzięgielewski, M.S. Przybyła, A. Gawlik (ed.), Migration in Bronze and Early Iron Age Europe (105-121). Prace Archeologiczne nr 63. Studies. Kraków.

Grant A. (1984). Animal Husbandry. In: B. Cunliffe (ed.), Danebury: an Iron Age hillfort in Hampshire, vol. 2. The Excavations 1969-1978 (496-548). London: Council for British Archaeology.

Habermehl K.H. (1975). Die Alterbestimmung bei Hausund Labortieren. Berlin: Parey.

Hillson S. (1999). Mammal bpnes and teeth. An Introductory Guide to Methods of Indentification. London: University of London Institute of Archaeology.

Hołub W. (1938). Studium nad użytkowościa owcy poleskiej. Kraków: PAN.

Howard M.M. (1963). The metrical attributes of two samples of bovine limb bones. Journal of Zoology, 157, 91-100.

Kaczanowski K., Kurnatowski S., Malinowski A., Piontek J. (1992). Zaludnienie ziem polskich między XIII w. p.n.e. a IV w. n.e. Materiaty źródtowe, próba oceny. Warszawa: Szkoła Główna Handlowa, Instytut Statystyki i Demografii.

Kobryń H. (1984). Zmiany niektórych cech morfologicznych konia w świetle badań kostnych materiałów wykopaliskowych z obszaru Polski. Rozprawy Naukowe, Monografie SGGW-AR, 42, 1-78.

Kobryń H., Lasota-Moskalewska A. (1989). Certain osteometric differences between the aurochs and domestic cattle. Acta Theriologica, 34(4), 67-82.

Kolda J. (1936). Srovnávací anatomie zviŕat domácích se žretelem $k$ anatomii člověka [Comparative anatomy of domestic animals with regard to human anatomy]. Brno: Novina [in Czech].

Kubasiewicz M., Pawlikowski J. (1976). Szczątki zwierzęce z osady kultury łużyckiej Grodziec, pow. Będzin. Rocznik Muzeum Okręgowego w Częstochowie. Archeologia, 1, 107-129.

Kurnatowski J. (1966). Przemiany techniki uprawy roli w czasach między epoka brązowa i wczesnym średniowieczem a rozmieszczenie stref zasiedlenia. Studia z Dziejów Gospodarstwa Wiejskiego 8, 93-96.

Kurzawska A. (2008). Śmietniska muszlowe na terenie Polski. In: D. Makowiecki et al. (eds), Badania archeozoologiczne w Polsce i Europie Środkowo-wschodniej. Materiaty - Metody - Interpretacje. III Sympozjum Archeologii Środowiskowej, Katowice-Koszęcin 26 29 listopada 2008. Środowisko i Kultura, t. 5 (59-63). Poznań: Seria Wydawnicza Stowarzyszenia Archeologii Środowiskowej.

Lasota-Moskalewska A. (1982-1984). The skeleton of a prehistoric cow, with characteristics of both Primigenious and Brachycerous cattle. Ossa, 9-11, 53-72.

Lasota-Moskalewska A. (1984). Morphotic changes of domestic cattle skeleton from the Neolithic Age to the beginning of the Iron Age. Wiadomości Archeologiczne, 45(2), 119-164.

Lasota-Moskalewska A. (2005). Zwierzęta udomowione $w$ dziejach ludzkości. Warszawa: Wydawnictwo Uniwersytetu Warszawskiego.

Lasota-Moskalewska A. (2008). Archeozoologia. Ssaki. Warszawa: Wydawnictwo Uniwersytetu Warszawskiego.

Lasota-Moskalewska A., Kobryń H., Świerzyński K. (1987). Changes in the size of the domestic and wild pig from the Neolithic to the Middle Age. Acta Theriologica, 32.

Levine M.A. (1983). Mortality models and the interpretation of horse population structure. In: G. Bailey (ed.), Hunter-gatherer economy in prehistory. An European perspective (23-46). Cambridge: Cambridge University.

Lityńska-Zając M. (1997). Środowisko i uprawa roślin w czasach pra- i wczesnohistorycznych. In: K. Tunia (ed.), Z archeologii Małopolski. Historia i stan badań zachodnio-małopolskiej wyżyny lessowej (460-482). Kraków: Polska Akademia Nauk. Instytut Archeologii i Etnologii.

Lutnicki W. (1972). Uzębienie zwierząt domowych. Warszawa-Kraków: PWN.

Lyman R.I. (1987). On the analysis of vertebrate mortality profiles: sample size, mortality type and hunting pressure. American Antiquity, 52 (1), 125-142. 
Makowiecki D., Makowiecka M. (1998). Gospodarka zwierzętami we wczesnej epoce brązu na Niżu Polskim w świetle źródeł archeozoologicznych. In: A. Kośko, J. Czebreszuk (eds), ,Trzciniec” - system kulturowy czy interkulturowy proces? (273-284). Poznań: Wydawnictwo Poznańskie.

Maltby J.M. (1985). Patterns in faunal assemblage variability. In: G. Barker, C. Gramble (eds), Beyond domestication in prehistoric Europe. Investigations in subsistence archaeology and social complexity (33-74). London: Academic Press.

Marciniak J. (1963). Tymczasowe sprawozdanie z archeologicznych badań ratowniczych w Witowie, pow. Kazimierza Wielka, w latach 1960-1961. Sprawozdania Archeologiczne, 15, 366-376.

Marciniak J. (1964). Sprawozdania z badań wykopaliskowych w Witowie, pow. Kazimierza Wielka, w 1962 roku. Sprawozdania Archeologiczne, 16, 324-329.

Marciniak J. (1965). Sprawozdanie z badań wykopaliskowych w Witowie, pow. Kazimierza Wielka, w 1963 roku. Sprawozdania Archeologiczne, 17, 119-124.

Marciniak J. (1966). Skarb brązowy z Witowa nad Wisłą. Rocznik Muzeum Świętokrzyskiego, 3, 75-92.

Marciniak A. (1996). Archeologia i jej źródła. Materiaty faunistyczne w praktyce badawczej archeologii. Warszawa-Poznań: Wydawnictwo Naukowe PWN.

Molenat M., Casabianca F. (1979). Contribution à la maîtrise de l'elevage porcin extensif en Corse (Bulletin Technique du Departement de Genetique Animale 32). Jouy-en-Josas: Institut National de la Recherche Agronomique.

Mrówka Ł. (2014). Struktury osadnicze we wczesnych fazach kultury łużyckiej na Górnym Śląsku. Rzeszów: Wyd. Uniwersytetu Rzeszowskiego.

Olszewski A. (2005). Atlas rozbioru tusz zwierząt rzeźnych. Warszawa: Wydawnictwo Naukowo Techniczne.

Piątkowska-Małecka J. (2013). Łowiectwo ssaków na ziemiach polskich od neolitu do okresu wędrówek ludów. Warszawa: Wydawnictwa Instytutu Archeologii UW.

Piątkowska-Małecka J., Anc K., Choromańska A., Gągała M., Kaczyńska J., Kur A. (2011). Gospodarowanie zwierzętami w osadzie ludności kultury łużyckiej w Grzybianach koło Legnicy, stan. 1 (woj. dolnośląskie). Światowit, 8(49), Fasc. B (2009-2010), 49-67.

Piątkowska-Małecka J., Gręzak A. (2007). Gospodarka zwierzętami ludności kultury łużyckiej na ziemiach Polskich. In: M. Makohonienko, D. Makowiecki, Z. Kurnatowska (eds), Badania archeozoologiczne $w$ Polsce i Europie Środkowo-wschodniej. Materiaty - Metody - Interpretacje. III Sympozjum Archeologii Środowiskowej, Środowisko i Kultura, Katowice-Ko- szęcin 26-29 listopada 2008, t. 5 (129-138). Poznań: Seria Wydawnicza Stowarzyszenia Archeologii Środowiskowej.

Piątkowska-Małecka J., Gubernat J. (2003). Pies w neolicie na ziemiach polskich. Światowit, 5, 207-241.

Przybyła M.S. (2017). The formation and breakdown of the Carpathian social networks - a discussion on the archaeological record from the Bronze Age Upper Vistula river. In: A. Rzeszotarska-Nowakiewicz (ed.), The Past Societies 4. 500 BC - 500 AD (187-257). Warszawa.

Reitz E.J., Wing E.S. (2008). Zooarchaeology, 2nd edition. Cambridge, U.K.: Cambridge University Press.

Rembisz A., Gackowski J., Makowiecki D., Markiewicz M., Polcyn M. (2009). Ślady gospodarki roślinnozwierzęcej ludności kultury łużyckich pól popielnicowych z osady w Rudzie, gmina Grudziądz, północna Polska. In: L. Domańska, P. Kittel, J. Forysiak (eds), Środowiskowe uwarunkowania lokalizacji osadnictwa. Środowisko - Człowiek - Cywilizacja, t. 2 (109122). Poznań: Seria wydawnicza Stowarzyszenia Archeologii Środowiskowej.

Rydzewski J. (1972). Badania poszukiwawcze i weryfikacyjne w dolnym dorzeczu Szreniawy. Sprawozdania Archeologiczne, 24, 267-294.

Rydzewski J. (1981). Możliwości rekonstrukcji gospodarki w epoce brązu i wczesnej epoce żelaza na terenie zachodniej Małopolski w świetle badań osadniczych. Acta Archaeologica Carpathica, 21, 227-235.

Rydzewski J. (1982). Przemiany w zasiedleniu zachodniomałopolskich wyżyn lessowych w czasach od kultury łużyckiej do kultury przeworskiej. In: Przemiany ludnościowe $i$ kulturowe I tysiaclecia p.n.e. na ziemiach między Odra a Dnieprem (213-240). Wrocław-Warszawa-Kraków-Gdańsk-Łódź: PAN.

Schmid E. (1972). Atlas of animal bones for prehistorians, archaeologists and Quaternary geologists. Amsterdam-London-New York: Elsevier Publishing Company.

Sobociński M. (1973). Szczątki kostne zwierząt z osady wielokulturowej w Dębnicy. Roczniki Akademii Rolniczej w Poznaniu LXVI. Wydziat Zootechniczny, 20, 105-120.

Urban J. (2019). Gospodarka rolna społeczności tzw. kultury tużyckiej. Warszawa: IAE PAN.

Wattenmaker P. (1987a). The organization of production and comnsumption in a complex society: a case study of a village site in Southeast Turkey. MASCA Journal, 4, 191-203.

Wattenmaker P. (1987b). Town and village economics in an early state society. Paleórient, 13(2), 113-122. 
Vigne J.-D. (1998). Faciès culturels et sous-système technique de l'acquisition des ressources animales. Application au Néolithique ancien méditerranéen. In: A. d'Anna, D. Binder (eds), Production et identité culturelle (Actes du colloque d'Antibes, novembre 1996) (27-45). Antibes: Éditions APDCA.

Zabilska M. (2012). Depozyty ze szczątkami mięczaków na stanowiskach kultury łużyckiej z Polski. Charakte- rystyka i próba określenia ich genezy. Acta Universitatis Nicolai Copernici. Archeologia, 22, 253-289.

Zeder M.A., Lapham H.A. (2010). Assessing the reliability of criteria used to identify postcranial bones in sheep, Ovis, and goats. J. Archaeol. Sci., 37(11), 2887-2905.

Zielińska U. (2009). Bone material from the Lusatian culture settlement in Witów. Recherches Archéologiques, 101-108.

Otrzymano (Received): 13.02.2020; Zrecenzowano (Revised): 11.03.2020; Zaakceptowano (Accepted): 31.03.2020

Author's address:

Dr Ulana Gocman

e-mail: ulanagocman@gmail.com

(iD https://orcid.org/0000-0003-3454-0040 